\title{
Analisis Management Bandwidth Menggunakan Metode Per Connection Queue (PCQ) dengan Authentikasi RADIUS
}

\author{
Abdul Syukur \\ Program Studi Teknik Informatika, Fakultas Teknik, Universitas Islam Riau \\ e-mail: abdulsyukur@eng.uir.ac.id
}

\begin{abstract}
Massive internet usage results in a decrease in network performance as network users grow. The way that can be taken to reduce the decline in network performance is by doing bandwidth management. Bandwidth management is very important in setting the allocation of bandwidth that will be given to the user to avoid seizing the existing bandwidth allocation in the network. MikroTik RouterOS is a derivative OS of the Debian linux distro that is specifically used as a router and gateway. MikroTik has QoS that is used to manage rational bandwidth usage. This study provides bandwidth distribution with Per Connection Queue (PCQ) method.
\end{abstract}

Keywords: MikroTik, Bandwidth, QoS, PCQ

\begin{abstract}
Abstrak
Penggunaan internet secara massal mengakibatkan menurunya performansi jaringan seiring dengan bertambahnya pengguna jaringan. Cara yang dapat ditempuh untuk mengurangi penurunan performansi jaringan yaitu dengan melakukan manajemen bandwidth. Manajemen bandwidth sangat penting dalam pengaturan alokasi bandwidth yang akan diberikan kepada user untuk menghindari perebutan alokasi bandwidth yang ada dijaringan. MikroTik RouterOS merupakan OS turunan dari distro linux Debian yang khusus digunakan sebagai router dan gateway. MikroTik memiliki QoS yang digunakan untuk mengatur penggunaan bandwidth secara rasional. Penelitian ini memberikan pembagian bandwidth dengan metode Per Connection Queue (PCQ).
\end{abstract}

Kata kunci: MikroTik, Bandwidth, QoS, PCQ

\section{PENDAHULUAN}

Router yang sudah selesai kita setting dan sudah berjalan, bukan berarti akan kita tinggalkan begitu saja. terlebih router tersebut merupakan router backbone. Pada kebanyakan ISP bahkan akan melakukan monitoring selama 24 jam nonstop untuk memastikan kondisi router baik-baik saja. Dan jika terjadi sesuatu pada router yang membuat jaringan tidak berjalan sebagaimana mestinya, bisa segera ditangani dengan baik. Begitu juga admin jaringan juga perlu mencatat penggunaan bandwidth untuk bahan laporan apakah bandwidth yang didapatkan sesuai dengan informasi layanan bandwidth dari ISP, atau sekedar mencatat statistik penggunaan bandwidth oleh client [2].

Mulai dari layanan komunikasi yang tidak membutuhkan layanan real time seperti mail, ftp, telnet sampai layanan komunikasi yang membutuhkan layanan real time seperti streaming voice, video dan sebagainya. Tiap-tiap layanan mempunyai karakteristik penggunaan jaringan yang berbeda-beda, maka manajemen bandwidth sangat diperlukan, metode manajemen bandwidth yang dapat digunakan atau diterapkan pada client yaitu metode Per Connection Queue (PCQ) [3].

Management bandwidth ini diharapkan dapat membagi bandwidth sesuai dengan kelas pengguna dan melihat pada kebutuhanya sehingga tidak mengganggu aktivitas 
akses pengguna yang lain. Dengan manajemen bandwidth, dapat dilakukan pengaturan bandwidth sesuai dengan kebutuhan. Penelitian ini membahas tentang manajemen bandwidth dengan memanfaatkan mikrotik sebagai Router. Pemanfaatan Mikrotik ini juga digunakan untuk manajemen bandwidth, kestabilan dan efisiensi software manajemen bandwidth serta keuntungan penggunaan mikrotik RouterOS untuk manajemen bandwidth [4].

Universitas Islam Riau merupakan sebuah universitas yang mempunyai bandwidth dengan menggunakan 2 line provider dengan total bandwidth sebesar $310 \mathrm{Mbps}$, jumlah pengguna jaringan internet diperkirakan sekitar 30.000 user.

\section{METODOLOGI PENELITIAN}

\subsection{Tinjauan Pustaka}

Dalam penelitian yang ditulis oleh Rr. Retna Trimantaraningsih, yang berjudul Imlpementasi MikroTik Sebagai Manajemen Bandwidth. Penelitian tersebut menjelaskan tentang perbedaan manajemen bandwidth menggunakan algoritma CBQ dan HTB.

Berdasarkan hasil penelitian diketahui bahwa: 1) hasil perbandingan antara CBQ dan HTB, pembagian bandwidth dapat dilakukan berdasarkan IP ataupun berdasarkan port atau kelas, 2) perbedaan antara algoritma CBQ dan HTB terletak pada scheduler dan estimator yang digunakan pada keduanya. HTB menggunakan scheduler DRR (Defiit Round Robin) dan estimator menggunakan TBF (Token Bucket Filter), sedangkan scheduler pada CBQ menggunakan WRR (Weight Round Robbin) dan estimator menggunakan EWMA (Exponent Weight Moving Averege), 3) kestabilan dan kecepatan transfer data cenderung sama, tergantung alokasi bandwidth yang diberikan dan ukuran data, 4) jika tidak diberikan alokasi bandwidth, maka tidak bisa untuk download dan upload meskipun antar klien terhubung ke PC router, dan 5) pembagian bandwidth dengan menggunakan mikrotik lebih mudah, karena ada aplikasi untuk remote dari klien dengan menggunakan winbox.

Berdasarkan tinjauan pustaka diatas penulis dapat mengambil kesimpulan bahwa management bandwidth dapat diterapkan dilingkungan kampus Universitas Islam Riau karena kampus UIR memiliki sembilan fakultas dan satu pascasarjana dengan alokasi bandwidth 300 Mbps dan tersebar sekitar 30.000 user. Algoritma dalam penelitian ini yaitu Per Connection Queue (PCQ) pada MikroTik.

\subsection{Pengumpulan Data}

Dalam metodologi penelitian ini dapat disimpulkan bahwa permasalahan yang dihadapi dengan kemajuan teknologi informasi seperti sekarang ini, Universistas Islam Riau tidak mungkin lagi dapat menghindar dari penggunaan jaringan komputer. Jumlah host network yang sudah terlalu kompleks maka perlu adanya monitoring trafik secara terpusat. Yang perlu diperhatikan adalah lingkup area komunikasi yang akan berhubungan, topologi jaringan, jenis protokol jaringan yang dipakai, serta mempersiapkan hardware network yang berkesesuaian dengan topologi dan jenis protokol yang digunakan [5]. 
Dilihat dari kendala yang akan dihadapi dengan pesatnya perkembangan teknologi informasi pada jaringan komputer Universitas Islam Riau, yaitu: Banyaknya user yang menggunakan internet dan host network yang tersebar sembilan fakultas dan satu pascasarjana sehingga diperlukan management bandwitdh secara merata.

Universitas Islam Riau telah mempunyai infrastruktur jaringan Local Area Network (LAN) untuk terkoneksi ke internet antara lain:

1. Switch (Unmanageable)

2. Access Point (AP)

3. Kabel Fiber Optic (FO) pada masing-masing fakultas dan rektorat.

4. Kabel Unsielded Twisted Pair (UTP)

5. Konektor RJ-45

6. Router MikroTik CCR 1036-12G-4S

7. Server Dedicated HP

\subsection{Kerangka Kerja (Frame Work)}

Dalam penelitian ini penulis menggunakan pendekatan air terjun (waterfall) bagi pengembangan dan penggunaan sistem [1]. Adapun kerangka kerja penelitian terdiri dari lima tahapan proses yang ditunjukkan seperti pada gambar 1 berikut ini:

1. Tahap Perencanaan (Planning)

2. Tahap Analisis (Analysis)

3. Tahap Rancangan (Design)

4. Tahap Penerapan (Implementation)

5. Tahap Penggunaan (Use)

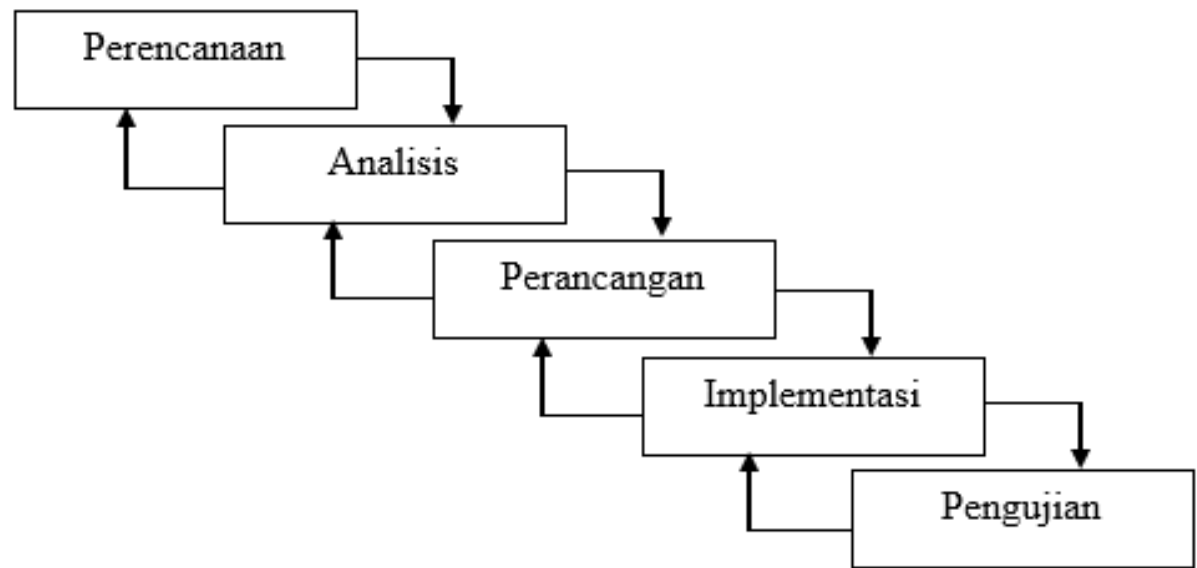

Gambar 1. Model Proses Waterfall

Sesuai dengan kerangka kerja yang telah diuraikan diatas, maka uraian kerangka kerja dituliskan sebagai berikut :

a. Tahap Perencanaan dan Analisis

Tahap awal yang akan dilakukan untuk menyelesaikan penelitian ini adalah dengan studi pendahuluan, yaitu mempelajari dan meneliti masalah yang akan dianalisa. Ruang lingkup masalah yang diteliti ataupun dianalisa harus ditentukan terlebih dahulu, karena tanpa menentukan serta mendefinisikan batasan masalah yang akan diteliti, maka tidak pernah ada solusi dari masalah tersebut. Jadi tahap pertama ini adalah tahap awal yang terpenting dalam penyelesaian penelitian ini. 


\section{b. Tahap Rancangan}

Hasil dalam mempelajari studi literatur, selanjutnya melakukan tahap analisis dengan menentukan kebutuhan-kebutuhan dalam perancangan dan penerapan management bandwidth. Tahap awal yang akan dilakukan adalah dengan membangun dan melengkapi kebutuhan apa-apa saja untuk merancang dan menerapkan management bandwidth. Adapun perangkat keras (hardware) yang dibutuhkan yaitu Switch Manageable dan router MikroTik dan beberapa unit komputer client. Dari sisi perangkat lunak (software) dengan menggunakan MikroTik OS dan beberapa konfigurasi router yang dibutuhkan.

\section{c. Implementasi}

Tahap implementasi ini merupakan tahap terakhir dari penelitian. Tahap ini lebih mengutamakan konfigurasi metode Per Connection Queue (PCQ). Pada tahap ini juga tidak tertutup kemungkinan untuk dilakukan pengembangan lebih lanjut seperti penggunaan authentikasi RADIUS untuk setiap user.

\section{ANALISA DAN PERANCANGAN}

a. Analisis dan Perancangan

Jaringan komputer yang akan dianalisis dalam penelitian ini adalah jaringan yang telah dibangun di Univeristas Islam Riau. Bentuk topologi jaringan Universitas Islam Riau secara umum menggunakan topologi ektended star, dengan menggunakan perangkat kabel Fiber Optik, Unsielded Twisted Pair (UTP), Wireless Fideliti (WiFi). Perangkat yang akan digunakan untuk router utama yaitu Mikrotik RouterBoard CCR 1036-12G-4S dengan menggunan aplikasi Winbox v3.11 untuk akses ke router.

b. Topologi Jaringan Universitas Islam Riau

Jaringan Universitas Islam Riau secara umum dikelola di Network Operation Center (NOC) Biro Adminstrasi Informasi dan Teknologi (BAIT) yang saat ini berganti menjadi Biro Sistem Informasi dan Komunikasi (SIMFOKOM) berdasarkan SK Rektor UIR Nomor : 306/UIR/KPTS/2017, distribusi bandwidth secara sentral terdistribusi kesemua fakultas di UIR melalui NOC ini.

Saat ini Universitas Islam Riau memiliki total bandwidth sebesar 300 Mbps. Bandwidth Universitas Islam Riau menggunakan dua Internet Service Proiver (ISP) yaitu, PT. Moratelindo dengan kapasitas bandwidth 200 Mbps dan PT. Nusanet dengan kapasitas bandwitdh 100 Mbps yang didisbusikan kesemua user civistas akademika Universitas Islam Riau, mulai dari Dosen, Karyawan, dan Mahasiswa.

Berikut ini merupakan topologi jaringan Universitas Islam Riau secara keseluruhan dan ditampilkan secara umum distribusi bandwidth dari NOC yang ada di Biro SIMFOKOM kesemua fakultas yang ada di Universitas Islam Riau. 


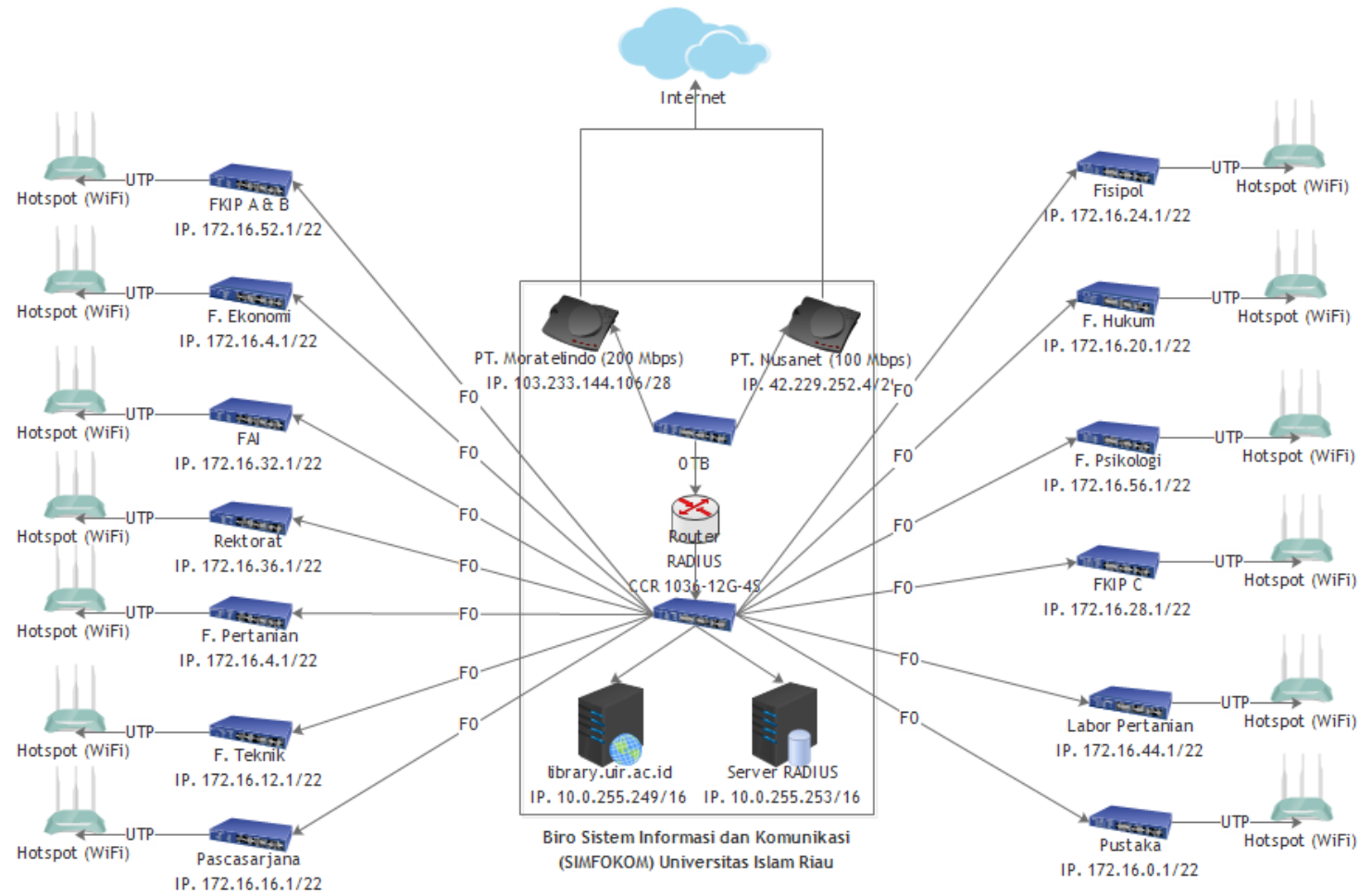

Gambar 2. Topologi Jaringan Universitas Islam Riau

c. Traffict Bandwidth Universitas Islam Riau

Universitas Islam Riau saat ini mempunyai total bandwidh sebesar $300 \mathrm{Mbps}$ dengan menggunakan 2 ISP. Berikut ini merupakan tampilan traffict bandwidth Universitas Islam Riau dengan menggunakan router Mikrotik RouterBoard CCR 103612G-4S yang diakses menggunakan software Winbox v3.11.

Pada kondisi traffict bandwidth Universitas Islam Riau pada gambar 3 terlihat bahwa total bandwidth dari PT. Moratelindo sebesar $200 \mathrm{Mbps}$ dan total bandwidth dari PT. Nusanet sebesar 100 Mbps yang dialokasikan secara merata kesetiap fakultas yang ada di Universitas Islam Riau berdasarkan kebutuhan penggunaan tiap-tiap fakultas. 
IT Journal Research and Development

Vol.2, No.2, Maret 2018

e-ISSN: 2528-4053

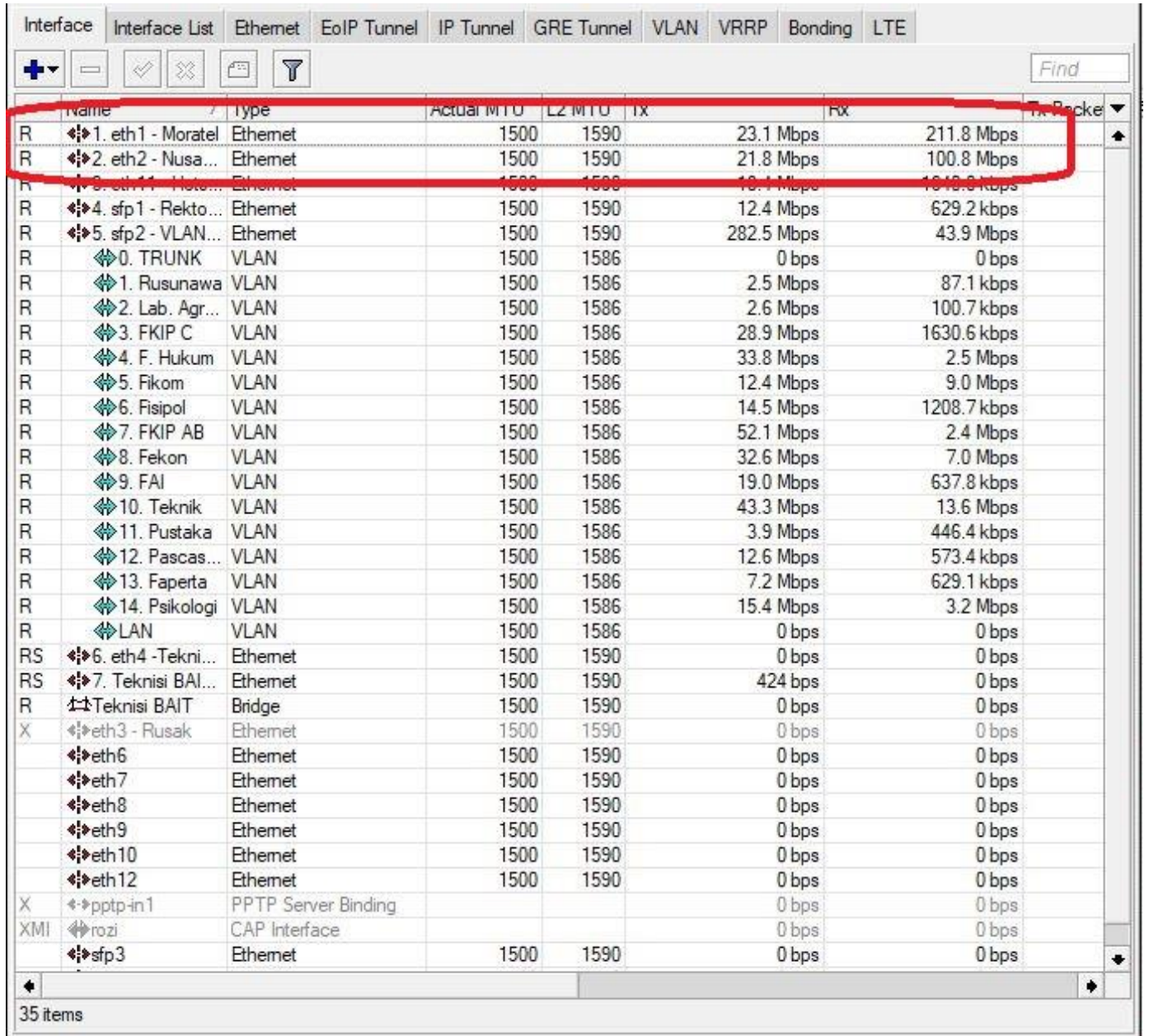

Gambar 3. Traffict Bandwidth Universitas Islam Riau

d. Total User RADIUS Universitas Islam Riau

Sistem Remote Access Dial-in User Service (RADIUS) Universitas Islam Riau menggukan Sistem Operasi Linux Ubuntu dengan aplikasi FreeRADIUS dan tool manajemen web menggunaka daloRADIUS.

Pada gambar 4 terlihat bahwa jumlah user RADIUS yang tersedia saat ini yaitu 57.897 user. User tersebut terbagi atas tiga group, yaitu Dosen, Karyawan, dan Mahasiswa. Dari total bandwidth $300 \mathrm{Mbps}$ yang dimiliki Universitas Islam Riau dialokasikan 100 Mbps untuk group Dosen, 100 Mbps untuk group Karyawan, dan 100 Mbps untuk group Mahasiswa.

User RADIUS dosen menggunakan account Akademik UIR, dan user RADIUS mahasiswa menggunakan account SIKAD UIR, dan user RADIUS karyawan menggunakan account NPK masing-masing. 


\section{((I))) dadolos}

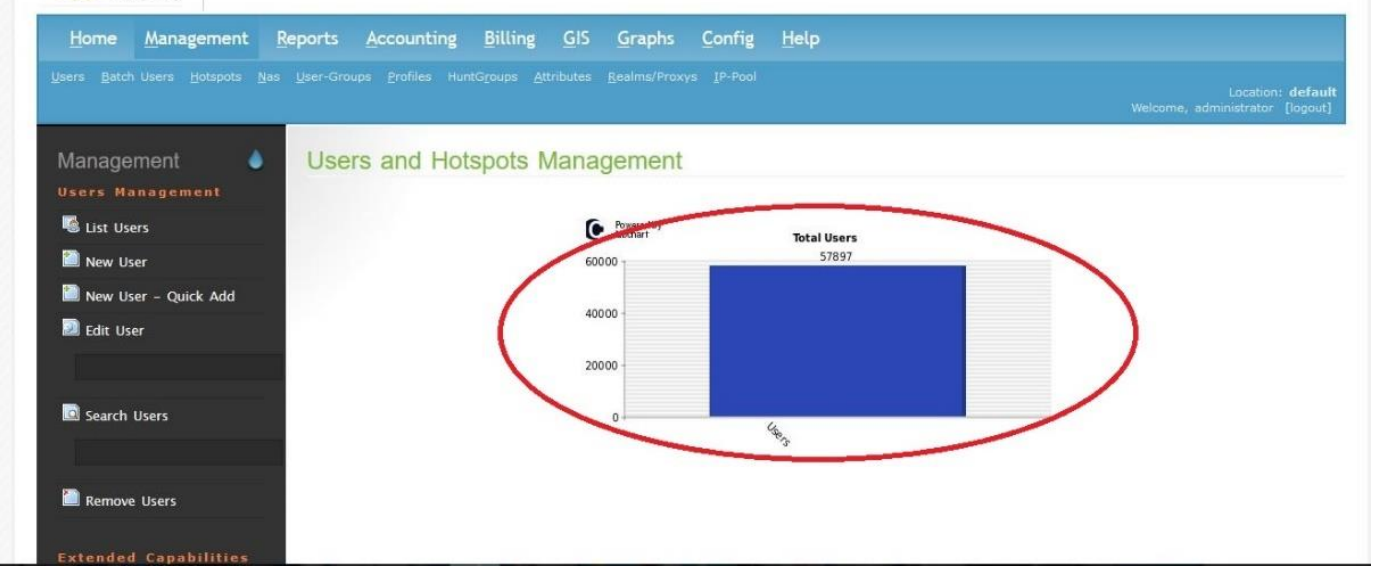

Gambar 4. Total User RADIUS Universitas Islam Riau

e. User RADIUS Dosen

Pada kondisi gambar 5 dapat dilihat user RADIUS untuk group dosen menggunakan account Akademik UIR, contoh : username 351syukur, password 654321.

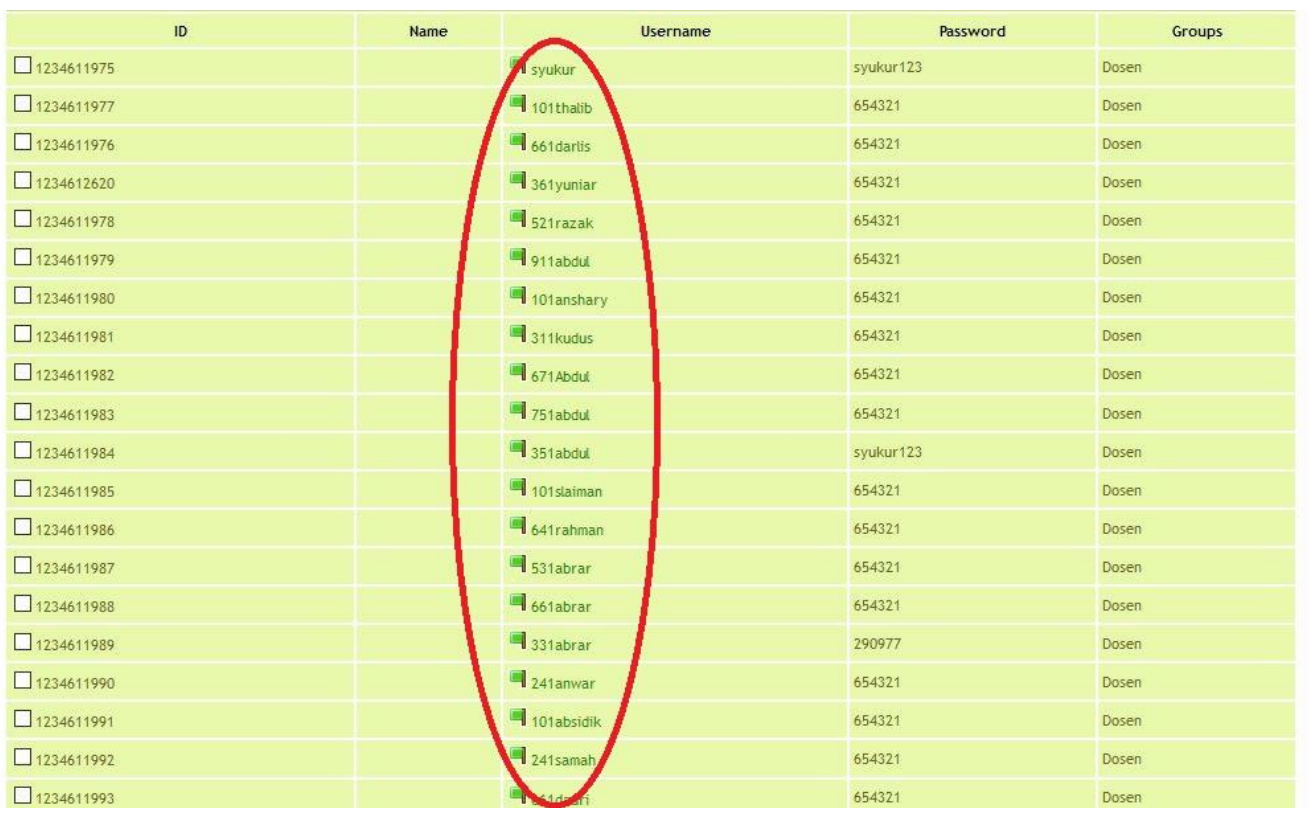

\section{Gambar 5. User RADIUS Dosen}

\section{f. User RADIUS Karyawan}

Pada kondisi gambar 6 dapat dilihat user RADIUS untuk group karyawan menggunakan NPK masing-masing, contoh : username 151002519, password 151002519. 


\section{Users Listing .}

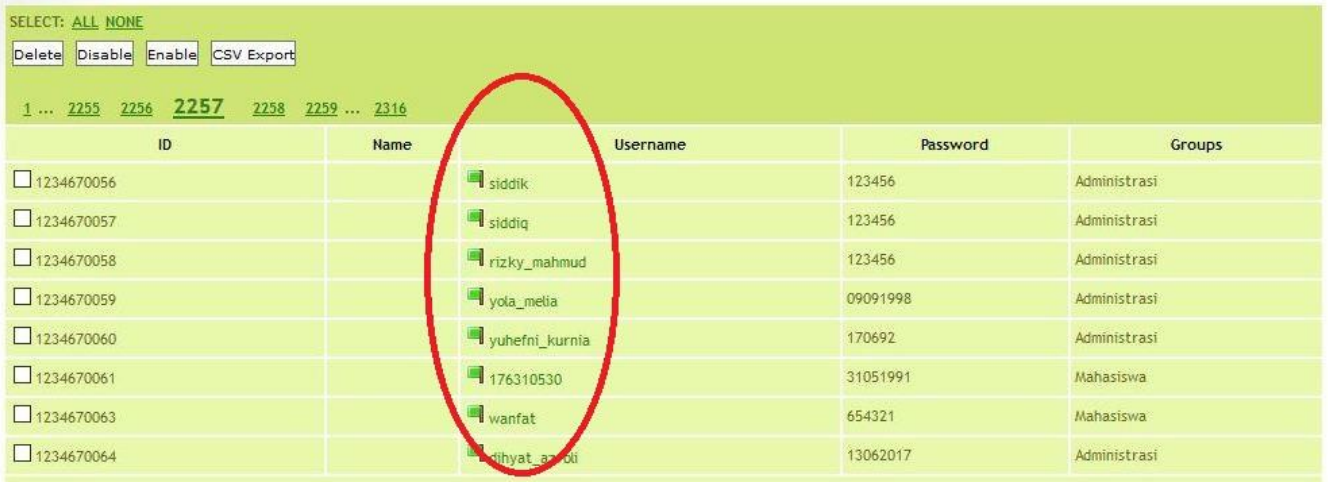

\section{Gambar 6. User RADIUS Karyawan}

\section{g. User RADIUS Mahasiswa}

Pada kondisi gambar 7 dapat dilihat user RADIUS untuk group mahasiswa menggunakan account SIKAD UIR, contoh : username 87420219, password 1011989.

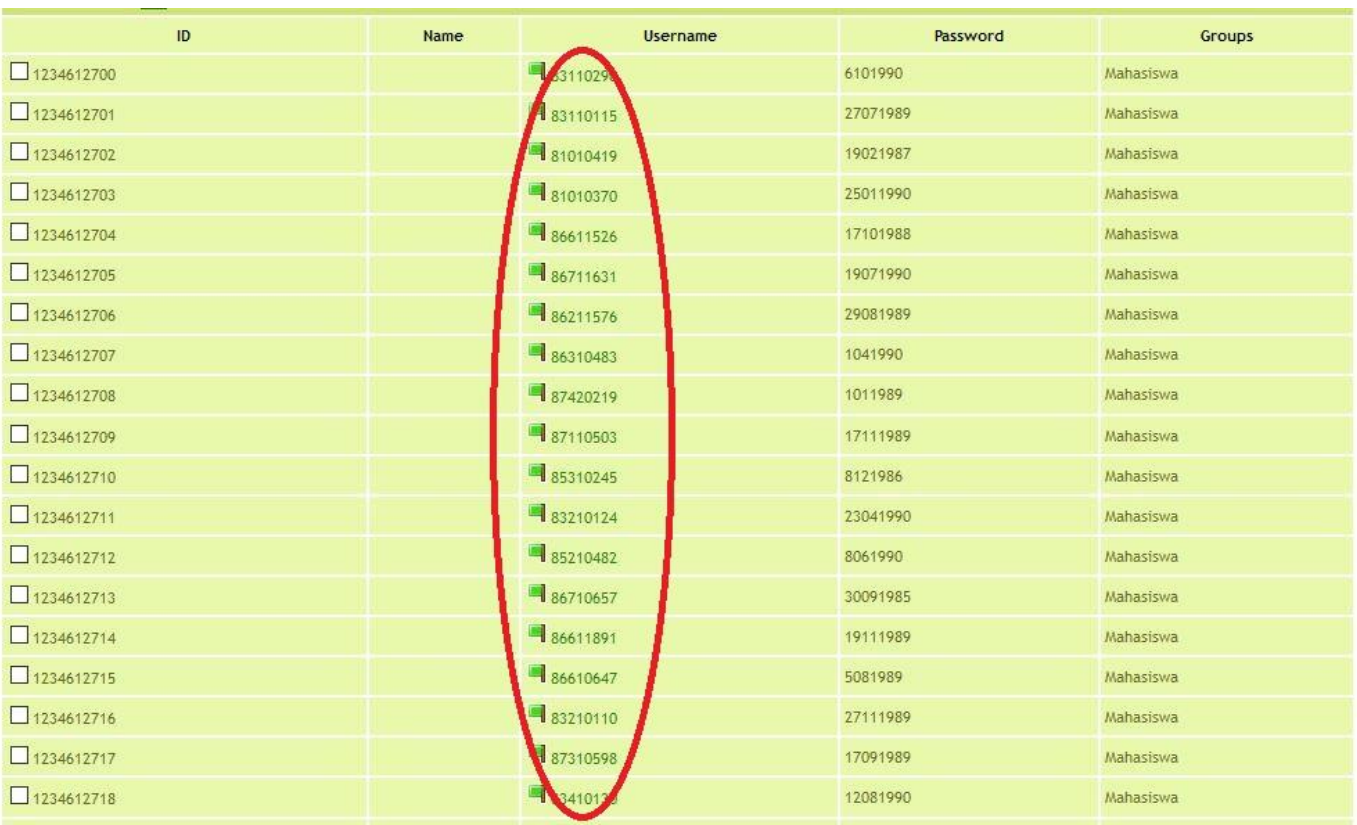

\section{Gambar 7. User RADIUS Mahasiswa}

h. Alokasi Bandwidth RADIUS Berdasarkan Group User

Pada kondisi gambar 8, terlihat masing-masing group dialokasi bandwidth secara merata, yaitu 100 Mbps untuk group dosen, 100 Mbps untuk group karyawan, dan 100 Mbps untuk group mahasiswa dengan konsekwensi atas dibagi secara merata pada masing-masing group.

Pada penelitian ini diasumsikan dosen yang ada di Universitas Islam Riau sebanyak 500 orang, maka pada waktu yang bersamaan semua dosen Universitas Islam Riau yang menggunakan internet mendapat alokasi bandwidth sebesar (100 Mbps : 500 orang) $=0,2$ Mbps. 
Untuk group karyawan yang ada di Universitas Islam Riau diasumsikan sebanyak 100 orang, maka pada waktu yang bersamaan semua karyawan Universitas Islam Riau yang menggunakan internet mendapat alokasi bandwidth sebesar (100 Mbps : 100 orang) $=1 \mathrm{Mbps}$.

Untuk group mahasiswa yang ada di Universitas Islam Riau diasumsikan sebanyak 20.000 orang, maka pada waktu yang bersamaan semua mahasiswa Universitas Islam Riau yang menggunakan internet mendapat alokasi bandwidth sebesar (100 Mbps : 20.000 orang $)=0.05$ Kbps.

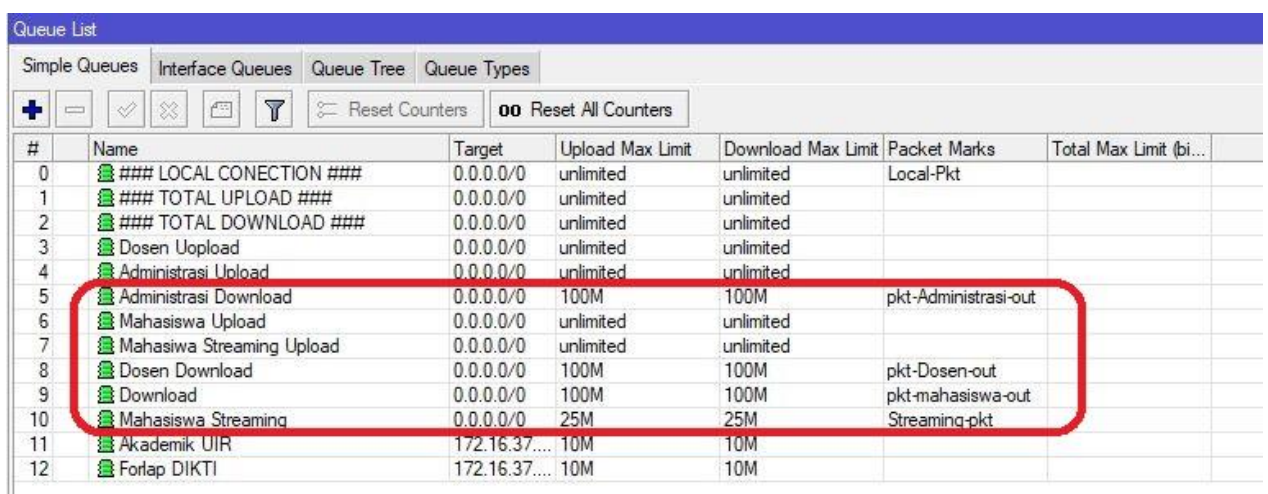

\section{Gambar 8. Alokasi Bandwidth RADIUS Berdasarkan Group User}

Pada penjelasan gambar 8 tentang alokasi bandwidth yang telah diuraikan diatas, pada penelitian ini untuk manajemen bandwidth menggunakan metode Simple Queues, yang akan mendistribukan bandwidth secara sederhana pada router Mikrotik. Adapun pembagian paket datanya berdasarkan paket output user dosen, paket outpun user karyawan, dan paket output user mahasiswa.

i. Kondisi Total User RADIUS yang Aktif Bersamaan

Pada kondisi gambar 9 terlihat total user RADIUS yang aktif secara bersamaan sebanyak 1.011 users, yang terdiri dari user dosen, karyawan, dan mahasiswa. Gambar 4.8 diakses pada tanggal 21 November 2017. 


\begin{tabular}{|c|c|c|c|c|c|c|c|c|c|}
\hline & Server , & User & Domain & Address & Uptime & Idle Time & Session Time & Rx Rate & Tx Rate \\
\hline $\mathrm{R}$ & 1. Rektora... & rifa & & 172.16 .37 .3 & $03: 36: 12$ & $00: 00: 05$ & & Obps & Obps \\
\hline $\mathrm{R}$ & (7) 1. Rektora... & Nopriadi & & 172.16.37.19 & $07: 35: 14$ & $00: 00: 16$ & & Obps & Obps \\
\hline $\mathrm{R}$ & (9) 1. Rektora... & ekamputra & & 172.16 .38 .22 & $00: 03: 51$ & $00: 03: 28$ & & Obps & Obps \\
\hline $\mathrm{R}$ & 91. Rektora. & 144310056 & & 172.16 .38 .23 & 00:05:41 & $00: 00: 01$ & & $3.4 \mathrm{kbps}$ & Obps \\
\hline $\mathrm{R}$ & 1. Rektora. & 144310127 & & 172.16 .38 .24 & $00: 06: 31$ & $00: 00: 08$ & & Obps & Obps \\
\hline $\mathrm{R}$ & (9) 1. Rektora... & 134310225 & & 172.16 .38 .25 & $00: 07: 46$ & $00: 00: 01$ & & $184.8 \mathrm{k}$. & $4.0 \mathrm{Mbps}$ \\
\hline $\mathrm{R}$ & 1. Rektora... & eti & & 172.16.37.27 & 03:49:54 & $00: 00: 02$ & & $16.2 \mathrm{~kb} .$. & $32.9 \mathrm{~kb} .$. \\
\hline $\mathrm{R}$ & 1. Rektora... & 123510668 & & 172.16 .38 .34 & $00: 24: 34$ & $00: 00: 27$ & & Obps & Obps \\
\hline $\mathrm{R}$ & 1. Rektora... & wely 27 & & 172.16 .37 .38 & $03: 48: 15$ & $00: 00: 01$ & & $206 \mathrm{bps}$ & Obps \\
\hline $\mathrm{R}$ & 1. Rektora. & Ekamputra & & 172.16 .36 .42 & $00: 37: 34$ & $00: 00: 02$ & & $17.8 \mathrm{~kb} .$. & $472.5 \mathrm{k}$. \\
\hline R & 1. Rektora.. & 137310666 & & 172.16 .38 .43 & $00: 16: 30$ & $00: 00: 03$ & & Obps & Obps \\
\hline $\mathrm{R}$ & (9) 1. Rektora... & 166310615 & & 172.16 .38 .50 & $00: 01: 10$ & $00: 00: 01$ & & $4.6 \mathrm{kbps}$ & $51.7 \mathrm{~kb} .$. \\
\hline $\mathrm{R}$ & 1. Rektora... & 145311003 & & 172.16 .38 .52 & $00: 39: 17$ & $00: 00: 01$ & & $160.1 \mathrm{k} \ldots$ & $1482.8 \ldots$ \\
\hline $\mathrm{R}$ & ㄱ. Rektora... & agung & & 172.16 .36 .63 & $00: 18: 29$ & $00: 00: 02$ & & $17.4 \mathrm{~kb} .$. & $483.6 \mathrm{k}$. \\
\hline $\mathrm{R}$ & 1. Rektora... & Opi & & 172.16 .37 .63 & $03: 23: 47$ & $00: 01: 10$ & & Obps & Obps \\
\hline $\mathrm{R}$ & 1. Rektora... & cici & & 172.16 .36 .86 & 06:12:04 & $00: 00: 05$ & & Obps & Obps \\
\hline $\mathrm{R}$ & 1. Rektora... & 110802423 & & 172.16 .36 .88 & $05: 47: 36$ & $00: 00: 04$ & & Obps & Obps \\
\hline$R$ & 1. Rektora... & 900302161 & & 172.16.36.96 & $06: 34: 38$ & $00: 00: 34$ & & Obps & Obps \\
\hline $\mathrm{R}$ & 1. Rektora... & 970102254 & & 172.16 .36 .98 & $01: 25: 30$ & $00: 02: 28$ & & Obps & Obps \\
\hline $\mathrm{R}$ & 7. 1. Rektora... & magang 3 & & 172.16 .36 .99 & $05: 47: 20$ & $00: 01: 21$ & & Obps & $0 \mathrm{bps}$ \\
\hline $\mathrm{R}$ & 1. Rektora... & 140602472 & & 172.16 .37 .110 & $02: 27: 34$ & $00: 00: 18$ & & Obps & Obps \\
\hline $\mathrm{R}$ & 91. Rektora... & 890902144 & & 172.16 .36 .111 & 01:21:08 & 00:00:01 & & 654 bps & $1251 \mathrm{bps}$ \\
\hline $\mathrm{R}$ & 1. Rektora... & lupi & & 172.16 .36 .114 & 04:33:06 & $00: 00: 02$ & & $427 \mathrm{bps}$ & 291 bps \\
\hline $\mathrm{R}$ & 1. Rektora... & Fenti & & 172.16 .36 .116 & $02: 57: 33$ & $00: 00: 07$ & & Obps & Obps \\
\hline $\mathrm{R}$ & 1. Rektora... & 960902243 & & 172.16 .36 .117 & $00: 20: 11$ & $00: 00: 03$ & & Obps & Obps \\
\hline $\mathrm{R}$ & 군 1. Rektora... & 980602273 & & 172.16 .36 .119 & $00: 13: 16$ & $00: 00: 01$ & & $3.3 \mathrm{kbps}$ & Obps \\
\hline $\mathrm{R}$ & (1. Rektora... & fenti & & 172.16 .36 .121 & $04: 59: 23$ & $00: 00: 09$ & & Obps & Obps \\
\hline $\mathrm{R}$ & 91. Rektora... & Pace & & 172.16 .36 .122 & $00: 15: 07$ & 00:00:01 & & $3.0 \mathrm{kbps}$ & $395.7 \mathrm{k} .$. \\
\hline $\mathrm{R}$ & 1. Rektora... & 970102255 & & 172.16 .38 .124 & $06: 00: 12$ & $00: 00: 04$ & & Obps & Obps \\
\hline $\mathrm{R}$ & 굽 1. Rektora... & Fenti & & 172.16 .36 .126 & $05: 48: 12$ & $00: 00: 01$ & & 890 bps & 532 bps \\
\hline $\mathrm{R}$ & (9) 1. Rektora... & nena1 & & 172.16 .36 .127 & 05:40:21 & $00: 00: 04$ & & Obps & Obps \\
\hline $\mathrm{R}$ & (1) 1. Rektora... & icha & & 172.16 .36 .137 & $05: 14: 23$ & $00: 00: 23$ & & Obps & Obps \\
\hline $\mathrm{R}$ & 1. Rektora... & prayudi & & 172.16 .36 .141 & 05:29:02 & $00: 00: 01$ & & $149.6 \mathrm{k}$. & $3.0 \mathrm{Mbps}$ \\
\hline $\mathrm{R}$ & (9) 1. Rektora... & 110102405 & & 172.16 .37 .142 & 02:33:01 & $00: 02: 28$ & & Obps & Obps \\
\hline $\mathrm{R}$ & (6) 1. Rektora... & tati & & 172.16 .37 .144 & $02: 46: 22$ & $00: 00: 08$ & & Obps & Obps \\
\hline$R$ & 9 1. Rektora... & novia & & 172.16.37.166 & $05: 26: 28$ & 00:00:01 & & $138 \mathrm{bps}$ & Obps \\
\hline $\mathrm{R}$ & (7) 1. Rektora... & Lupi & & 172.16 .36 .173 & $01: 07: 54$ & $00: 00: 17$ & & Obps & Obps \\
\hline$=$ & & 120702438 & & 17216.6176 & $05.51 \cdot 01$ & $0 n \cdot 00 \cdot 3 n$ & & Ohns & Ohne \\
\hline
\end{tabular}

\section{Gambar 9. Kondisi Total User RADIUS yang Aktif Bersamaan}

j. Kondisi User RADIUS Pengguna Internet UIR Dalam Satu Hari

Pada kondisi gambar 10 terlihat total user pengguna internet Universitas Islam Riau dalam satu hari sebanyak 9.948 users yang terdiri dari user dosen, karyawan, dan mahasiswa dan sifatnya mengakses internet bukan secara bersamaan. Gambar 4.9 diakses pada tanggal 19 Oktober 2017. 


\begin{tabular}{|c|c|c|c|c|c|c|c|c|c|}
\hline & Address & MAC Address & Cient ID & Server & Address List & $\Gamma$ Active Address & Active MAC Addre.. & Active Hos.. & Expires After \\
\hline & $\begin{array}{l}\text { ". Server LibUIR - } \\
10.0 .255 .249\end{array}$ & $\begin{array}{l}\text { BAlT } \\
\text { D8:D3:85:64:AC:A4 }\end{array}$ & & dhcp12- Ho... & & 10.0255 .249 & $D 8: D 3: 85: 64: A C \cdot A 4$ & thibuir & $14: 17: 12$ bound \\
\hline & :: PC Irwan Hakiki & (Operator IT FE) & & & & & & & \\
\hline & 172.16 .4 .190 & 50:AF:73:23:CE:9B & 1:50:af:73:23:ce:9b & dhcp 4 - Fekon & & 172.16 .4 .190 & 50:AF:73:23:CE:9B & CyberCrim.... & 02:39:59 bound \\
\hline & :- PC Muhammad, & Amin (Operator IT FKI & & & & & & & \\
\hline & $\begin{array}{l}\text { 172.16.28.191 } \\
\text { :. PC Firdaweli Sul }\end{array}$ & $\begin{array}{l}\text { 50:AF:73:23:CE:A3 } \\
\text { lasmi (BAA) }\end{array}$ & 1:50:af:73:23:ce:a3 & dhcp 10 - FKI... & & 172.16.28.191 & 50:AF:73:23:CE:A3 & EMP-PC & 18:45:18 bound \\
\hline & $\begin{array}{l}172.16 .37 .214 \\
\text { PC Yanu Ismaw }\end{array}$ & $\begin{array}{l}\text { D8:CB:8A:D9:B9:29 } \\
\text { an (Operator IT FAI) }\end{array}$ & 1:d8:cb:8a:d9:b9:... & dhcp 1-Rek... & & 172.16 .37 .214 & D8:CB:8A:D9:B9:29 & Lenovo & 20:19:50 bound \\
\hline & 172.16 .33 .247 & 50:AF:73:23:CE:A7 & 1:50:af: $73: 23: c e: a 7$ & dhcp 11-FAl & & 172.16 .33 .247 & 50:AF:73:23:CE:A7 & Yanu-PC & 18:38:57 bound \\
\hline & :. PC Zulfadli (Ope & rator IT F. Teknik) & & & & & & & \\
\hline & $\begin{array}{l}172.16 .13 .56 \\
\text {. Server Labor } \mathrm{Ba}\end{array}$ & $\begin{array}{l}\text { 50:AF:73:23:CE:2E } \\
\text { hasa-BAIT }\end{array}$ & 1:50:af:73:23:ce:2e & dhcp $15-$ Te. & & 172.16 .13 .56 & 50:AF:73:23:CE:2E & OHAYO-PC & 02:34:46 bound \\
\hline & 10.0 .255 .248 & EC:A8:6B:21:18:9C & & dhcp 12 - Ho... & & & & Lab-PC & watiting \\
\hline & :. Server LibUIR - & Pustaka & & & & & & & \\
\hline & 172.16.3.254 & $6 C: 71: D 9: 8 D: F 5: 28$ & & dhcp 12 - Ho... & & & & & watting \\
\hline & .: PC Novia Huma & irah (BAIT) & & & & & & & \\
\hline & $\begin{array}{l}172.16 .37 .166 \\
\text { PC Dwi Rahajo }\end{array}$ & $\begin{array}{l}\text { 74:D4:35:A6:94:2F } \\
\text { Operator PDPT BAIT }\end{array}$ & $\begin{array}{l}1: 74: d 4: 35: a 6: 94: 27 \\
T\end{array}$ & dhcp 1-Rek... & & & & BAIT-PC & walting \\
\hline & 172.16 .37 .157 & FC:AA:14:02:30:4F & 1fc:aa: $14: 2: 3 \mathrm{~d}: 4 \mathrm{f}$ & dhcp 1-Rek... & & & & PDPT.PC & watiting \\
\hline & ... PC Pak Toralia & (Operator IT BKH) & & & & & & & \\
\hline & $\begin{array}{l}\text { 172.16.37.124 } \\
\text { PC Ridho Lesm }\end{array}$ & $\begin{array}{l}94: D E: 80: D D: C 4: 59 \\
\text { ana (Operator IT F. Psi }\end{array}$ & $\begin{array}{l}\text { 1:94:de:80:dd:c4:... } \\
\text { ikologi) }\end{array}$ & dhcp 1 - Rek... & & & & TORA-PC & watting \\
\hline & 172.16 .58 .163 & 18:CF:5E:57:5F:87 & $1: 18: c f: 5 e: 57: 5 f: 87$ & dhcp 17- Psi... & & & & nidho $\cdot \mathrm{PC}$ & waiting \\
\hline D & 172.16 .20 .36 & O0:0A:00:72:69:29 & & dhcp $8-F H \ldots$ & & 172.16 .20 .36 & 00:0A:00:72:69:29 & android bc.. & 02:03:16 bound \\
\hline D & 172.16 .39 .64 & C4:OB:CB:OF::FF:FB & 1:c4:b:cbf:9f:fb & dhcp 1 - Rek.... & & 172.16 .39 .64 & C4:OB:CB:OF:9F:FB & Redmi4A-... & $23: 00: 33$ bound \\
\hline & 172.16 .2 .63 & 00:EC:0A:6C:93:A0 & 1:0:ec:a:6c:93:a0 & dhcp 3 - Pust... & & 172.16 .2 .63 & $00: E C: 0 A: 6 C: 93: A 0$ & RedmiNot... & $00: 26: 22$ bound \\
\hline & 172.16 .2 .18 & 30:CB:F8:F7:A8:1F & 1:30:cb. $88 \mathrm{f7}: \mathrm{a8}: 1 \mathrm{ff}$ & dhcp 3 - Pust... & & 172.16 .2 .18 & 30:CB:F8:F7:A8:1F & android eb.. & 00:26:41 bound \\
\hline & 172.16 .34 .102 & 00:71:CC:7A::BC:98 & 1:0:71:cc:7a:8c:98 & dhcp 11 - FAl & & 172.16 .34 .102 & 00:71:CC:7A:8C:98 & BRW0071.. & 19:17:56 bound \\
\hline D & 172.16 .49 .255 & $\mathrm{EC}: \mathrm{DO}: 9 \mathrm{~F}: \mathrm{AD}: 3 \mathrm{~B}: \ldots$ & 1:ec:d0:9f:ad:3b:ef & dhcp6 - Fikom & & 172.16 .49 .255 & EC:DO:9F:AD:3B:... & Redmi4A-... & $00: 30: 45$ bound \\
\hline & 172.16 .34 .105 & 1C:77:F6:E3:F2:16 & & dhcp 11 - FAl & & 172.16 .34 .105 & $1 C: 77: F 6: E 3: F 2: 16$ & android- $33 \ldots$ & $00: 31: 53$ bound \\
\hline D & 172.16 .9 .240 & $08: 8 C: 2 \mathrm{C}: 03 \cdot \mathrm{FF}: 05$ & $1: 8: 8 c: 2 c: 3 f f: 5$ & dhcp5 - Fap... & & 172.16 .9 .240 & 08:BC:2C:03:FF:05 & android b $7 . .$. & $00: 26: 58$ bound \\
\hline D & 172.16 .29 .146 & $28: 83: 35: 87: 74: 94$ & $1: 28: 83: 35: 87: 74 \ldots$ & dhcp 10 - FKI.. & & 172.16 .29 .146 & $28: 83: 35: 87: 74: 94$ & android $-93 \ldots$ & 22:21:24 bound \\
\hline & 172.16 .34 .13 & $24: 00: B A: 85: 8 C: 9 F$ & & dhcp 11 - FAl & & 172.16 .34 .13 & 24:00:BA:85:8C:9F & android-9d... & 01:45:40 bound \\
\hline & 172.16 .2 .65 & 20:5E:F7:22:14:C4 & $1: 20: 5 e \cdot f 7: 22: 14: 04$ & dhcp 3-Pust. & & 172.16 .2 .65 & $20: 5 E: F 7: 22: 14: C 4$ & android-18. & 22:33:08 bound \\
\hline & 172.16 .2 .66 & CC:2D:83:88:12:5E & & dhcp 3 - Pust. & & 172.16 .2 .66 & CC:2D:83:88:12:5E & android-aa.. & $00: 27: 06$ bound \\
\hline & 172.16 .31 .250 & CC: $2 D: 83: 9 C: 74: 9 A$ & & dhcp 10 - FKI.... & & 172.16 .31 .250 & CC: $2 D: 83: 9 C: 74: 9 \mathrm{~A}$ & android b1... & 01:12:48 bound \\
\hline & 177916.49525 & 20:CR:FB:FA:A5:8n & 1.:30.ch+8. $+4 \cdot 45 \cdot 8 d$ & dhrnf. Fiknm & & 17216.49253 & 3D. $C R \cdot F R \cdot F A \cdot A 5: B n$ & andmidthr & 22.27 .24 hound \\
\hline
\end{tabular}

\section{Gambar 10. Kondisi Total User Pengguna Internet UIR per Hari}

\section{KESIMPULAN}

Berdasarkan pembahasan pada penelitian ini diperoleh beberapa kesimpulan, antara lain:

1. Semua device dengan jaringan dapat menggunakan internet dengan lancar dan stabil walaupun semua unit menggunakan internet dalam waktu yang bersamaan

2. Semua bagian unit komputer mendapat bandwidth sesuai dengan kebutuhan koneksi internet

3. Manajemen bandwidth dapat memaksimalkan bandwidth disemua unit komputer

4. Membantu admin jaringan dalam mengontrol bandwidth Universitas Islam Riau

5. Membantu admin jaringan dalam mengontrol pengguna internet di Universitas Islam Riau, seperti Dosen, Karyawan, dan Mahasiswa

\section{SARAN} antara lain:

Berdasarkan pembahasan pada penelitian ini maka dapat dibuat beberapa saran,

1. Membuat schedule pada Mikrotik Router untuk pemblokiran situs tertentu seperti youtube.com dan facebook.com, dan pada jam tertentu seperti jam kerja kantor

2. Limitasi bandwidth pada jam tertentu.

\section{DAFTAR PUSTAKA}

[1] A. Syukur, "Implementasi Learning Management System (LMS) Berbasis Open Source Untuk Meningkatkan Kualitas Pembelajaran Siswa," Prosiding SNaPP: Sains, Teknologi, vol. 4, pp. 389-396, 2014.

[2] Mansfield Niall, 2004, Practical TCP/IP: Mendesain, Menggunakan, dan Troubleshooting Jaringan TCP/IP di Linux dan Windows, Jilid 1, Andi, Yogyakarta 
[3] Mansfield Niall, 2004, Practical TCP/IP: Mendesain, Menggunakan, dan Troubleshooting Jaringan TCP/IP di Linux dan Windows, Jilid 2, Andi, Yogyakarta

[4] Husni, 2004, Implementasi Jaringan Komputer dengan Linux Redhat 9, Andi, Yogyakarta

[5] Winarno Sugeng, 2010, Jaringan Komputer dengan TCP/IP, Modula. Bandung

[6] Sofana Iwan, 2012, Cisco, CCNP, dan Jaringan Komputer, Informatika. Bandung 